\title{
Apical Secretion of Lysosomal Enzymes in Rabbit Pancreas Occurs Via a Secretagogue Regulated Pathway and Is Increased after Pancreatic Duct Obstruction
}

\author{
T. Hirano, A. Saluja, P. Ramarao, M. M. Lerch, M. Saluja and M. L. Steer \\ Department of Surgery and Harvard Digestive Diseases Center Beth Israel Hospital \\ and Harvard Medical School, Boston, Massachusetts 02215
}

\begin{abstract}
Lysosomal hydrolases such as cathepsin B are apically secreted from rabbit pancreatic acinar cells via a regulated as opposed to a constitutive pathway. Intravenous infusion of the cholecystokinin analogue caerulein results in highly correlated apical secretion of digestive and lysosomal enzymes, suggesting that they are discharged from the same presecretory compartment (zymogen granules). Lysosomal enzymes appear to enter that compartment as a result of missorting. After $7 \mathrm{~h}$ of duct obstruction is relieved, caerulein-stimulated apical secretion of cathepsin $B$ and amylase is increased, but the ratio of cathepsin $B$ to amylase secretion is not different than that following caerulein stimulation of animals never obstructed. These findings indicate that duct obstruction causes an increased amount of both lysosomal and digestive enzymes to accumulate within the secretagogue releasable compartment but that duct obstruction does not increase the degree of lysosomal enzyme missorting into that compartment. Pancreatic duct obstruction causes lysosomal hydrolases to become colocalized with digestive enzymes in organelles that, in size and distribution, resemble zymogen granules but that are not subject to secretion in response to secretagogue stimulation. These organelles may be of importance in the development of pancreatitis. (J. Clin. Invest. 1991. 87:865-869.) Key words: pancreatitis • cathepsin B • digestive enzymes $\bullet$ intracellular trafficking $\bullet$ cell polarity
\end{abstract}

\section{Introduction}

Lysosomal hydrolases are synthesized on the endoplasmic reticulum, and along with other newly synthesized proteins including structural proteins and digestive zymogens, are transported to the Golgi complex. During transit through the Golgi complex, lysosomal hydrolases are glycosylated, 6-mannose phosphorylated, and bound by 6-mannose phosphate-specific receptors (1). As a result, the bound lysosomal hydrolases are diverted towards the lysosomal compartment and away from the pathway(s) by which proteins such as digestive zymogens are exported from the cell.

Rinderknecht and colleagues (2) have reported that lysosomal enzymes can be detected in human pancreatic juice and that the secretion of some, but not all, lysosomal hydrolases

\footnotetext{
Address correspondence to Dr. Michael L. Steer, Beth Israel Hospital Department of Surgery, 330 Brookline Ave., Boston, MA 02215.

Received for publication 25 June 1990 and in revised form 17 September 1990.
}

J. Clin. Invest.

(C) The American Society for Clinical Investigation, Inc. $0021-9738 / 91 / 03 / 0865 / 05 \quad \$ 2.00$

Volume 87, March 1991, 865-869 can be stimulated by the digestive enzyme secretagogue cholecystokinin (CCK). ${ }^{1}$ We have reported the results of a large number of studies that suggest that lysosomal hydrolases may play an important role in the pathogenesis of acute pancreatitis. In a recent communication, we noted that obstruction of the rabbit pancreatic duct for $7 \mathrm{~h}$ causes subcellular redistribution of lysosomal hydrolases and the appearance of lysosomal hydrolases in organelles that, by their size and distribution, resemble zymogen granules (3). These observations led us to suspect that pancreatic duct obstruction might have an important effect on lysosomal enzyme secretion.

Surprisingly, little is known of the mechanisms responsible for lysosomal enzyme secretion. Most of the studies evaluating this phenomenon have been performed using nonpolarized cell types, and the results of those studies have indicated that, under most conditions, lysosomal enzymes are secreted in a constitutive manner $(4,5)$. In this paper, we report the results of studies that have characterized lysosomal enzyme secretion from the exocrine pancreas. Pancreatic acinar cells are believed to secrete digestive enzymes exclusively at the apical surface of the cell, and in these cells, digestive enzyme secretion occurs primarily via a well-characterized regulated pathway. We report that a small fraction of the pancreatic content of lysosomal hydrolases is released from the apical surface of pancreatic cells under resting conditions and that intravenous infusion of the cholecystokinin analogue caerulein increases the rate of lysosomal enzyme secretion from the apical cell surface. This increased rate of lysosomal enzyme secretion closely parallels the enhanced rate of digestive enzyme secretion stimulated by caerulein infusion. These observations indicate that the apical secretion of lysosomal hydrolases from the exocrine pancreas occurs primarily via the regulated rather than via the constitutive pathway. Relief of pancreatic duct obstruction was found to increase the magnitude of secretagogue-stimulated lysosomal as well as digestive enzyme secretion. Since the lysosomal hydrolase cathepsin B can activate trypsinogen $(6,7)$ and trypsin can activate the remaining digestive zymogens, these observations may help to further elucidate events that underlie the development of pancreatitis.

\section{Methods}

All experiments were performed using New Zealand rabbits of either sex, weighing 2.2-3.0 kg, purchased from Pine Acre Rabbitary (West Brattleboro, VT). They were housed in light/dark cycle-regulated, airconditioned $\left(23 \pm 3^{\circ} \mathrm{C}\right)$ quarters and fasted for $16 \mathrm{~h}$ before each experiment. Caerulein and secretin were purchased from Sigma Chemical Co. (St. Louis, MO). CBZ-arginyl-arginine $\beta$-naphthylamide was from Bachem Biosciences (Philadelphia, PA) and $\beta$-naphthylamide from Sigma Chemical Co. Leucine-2-naphthylamide, 4-methylumbelliferyl

1. Abbreviation used in this paper: CCK, cholecystolcinin. 
sulfate, 4-methylumbelliferyl $N$-acetyl $\beta$-D-galactosaminide, and 4methylumbelliferyl $N$-acetyl $\beta$-D-glucosaminide were purchased from Sigma Chemical Co. All other reagents were of the highest purity commercially available.

Animal preparation. Rabbits were anesthetized with intravenously administered pentobarbitol $(35 \mathrm{mg} / \mathrm{kg}$ initially, supplemented by periodic doses of $10 \mathrm{mg} / \mathrm{kg}$ as needed) and a cannula (PE 50) was introduced into the inferior vena cava via the femoral vein. After upper abdominal midline laparotomy, the pylorus was ligated and a drainage gastrostomy cannula (PE 70) was placed. The pancreatic duct was cannulated (PE 10) extraduodenally. After placement and exteriorization of the various cannulas, the abdominal wound was closed. Core temperature was maintained using a heating pad and overhead lamp. To stimulate and maintain pancreatic fluid secretion, secretin was infused through the venous catheter at a rate calculated to deliver $2.0 \mathrm{U} / \mathrm{kg} / \mathrm{h}$. When indicated, pancreatic ductal obstruction was produced, after an initial 30-min period for stabilization, by raising the ductal cannula to a vertical position and allowing the column of secreted juice to rise until it reached a steady-state level (usually $17-20 \mathrm{~cm}$ above the level of the pancreas). In nonobstructed animals, the ductal cannula was maintained in a horizontal position to permit the free flow of juice. After completion of each experiment, the animal was killed, the serum amylase activity was measured, the degree of pancreatic edema was evaluated, and the subcellular distribution of amylase as well as cathepsin B was determined as recently described (3). In each instance, duct-obstructed animals were found to have profound hyperamylasemia, pancreatic edema, and subcellular redistribution of both amylase and cathepsin B. In contrast, only mild degrees of hyperamylasemia and neither pancreatic edema nor cathepsin B redistribution was noted in the nonobstructed rabbits. The observations were consistent with those recently reported from this laboratory (3).

Enzyme assays. Amylase was measured according to Bernfeld (8) using soluble starch as the substrate. $1 \mathrm{U}$ of activity is defined as that which liberates $1 \mathrm{mg}$ of maltose per minute at $30^{\circ} \mathrm{C}$. Cathepsin B was measured as described by McDonald and Ellis using CBZ-arginyl arginine $\beta$-naphthylamide as the substrate (9). $1 \mathrm{U}$ of activity is defined as that which liberates $1 \mathrm{nmol}$ of $\beta$-naphthylamide per $5 \mathrm{~min}$ at $37^{\circ} \mathrm{C}$. Leucine naphthylamidase, $N$-acetyl $\beta$-D-galactosidase, $N$-acetyl $\beta$-Dglucosaminidase, and aryl sulfatase were assayed as described by others (2). $1 \mathrm{U}$ of leucine naphthylamidase activity is defined as that which liberates $1 \mathrm{nmol}$ of product in $20 \mathrm{~min}$ at $25^{\circ} \mathrm{C}$. $1 \mathrm{U}$ of $\beta$-D-glucosaminidase activity is defined as that which liberates $1 \mathrm{nmol}$ of product in $\mathbf{3 0}$ min at $25^{\circ} \mathrm{C} .1 \mathrm{U}$ of aryl sulfatase and $\beta$-D-galactosaminidase activity is defined as that which liberates $1 \mathrm{nmol}$ of product in $30 \mathrm{~min}$ at $37^{\circ} \mathrm{C}$. Protein was estimated as described by Lowry et al. (10).

Data presentation. The results reported in this paper represent the mean \pm SEM values for $n$ determinations each obtained using a different animal. The significance of changes was evaluated using Student's $t$ test. A $P$ value of $<0.05$ was considered to be significant.

\section{Results}

\section{Caerulein stimulation of lysosomal enzyme and amylase} secretion.

Infusion of secretin $(2 \mathrm{U} / \mathrm{kg} / \mathrm{h})$ alone was found to result in near negligible rates of amylase and cathepsin $B$ secretion into the pancreatic juice. Addition of caerulein to the infusate resulted in a dose-dependent stimulation of both amylase and cathepsin B output (Fig. $1 A$ and $B$ ) that was detectable in the presence of $0.2 \mu \mathrm{g} / \mathrm{kg} / \mathrm{h}$ caerulein and reached a maximal rate in the presence of $1.0 \mu \mathrm{g} / \mathrm{kg} / \mathrm{h}$ caerulein. This maximal rate of enzyme secretion, stimulated by $1.0 \mu \mathrm{g} / \mathrm{kg} / \mathrm{h}$ caerulein, was inhibited by infusion of a higher dose of caerulein $(2.0 \mu \mathrm{g} / \mathrm{kg} / \mathrm{h})$. Caerulein stimulation of cathepsin $B$ and amylase secretion was constant for $3 \mathrm{~h}$, and as a result, the dose-dependent stimulation noted for $1 \mathrm{~h}$ of stimulation (Fig. $1 \mathrm{~A}$ ) was almost identical to that found for $3 \mathrm{~h}$ of stimulation (Fig. $1 B$ ). There was a close correlation $(P<0.01)$ between the output of amylase and of cathepsin $B$ that occurred in the presence of each of the doses of caerulein tested $(0.2-2.0 \mu \mathrm{g} / \mathrm{kg} / \mathrm{h}$, Fig. 2). The relationship between amylase and cathepsin $B$ output in response to each of the doses was similar, i.e., when analyzed individually, the regression line obtained for each dose was not significantly different from that obtained by combining the results for the remaining secretagogue doses. Caerulein was also noted to stimulate the secretion of a number of other lysosomal hydrolases into the pancreatic duct (Table I). In each instance, secretin alone caused only mild degrees of lysosomal enzyme secretion, while addition of caerulein $(0.5 \mu \mathrm{g} / \mathrm{kg} / \mathrm{h})$ caused a roughly threefold stimulation of secretion for each of the four lysosomal enzymes studied.

Fractional output of amylase and cathepsin B. Preliminary studies were performed to define the percent of total pancreatic amylase and cathepsin B contained within the splenic lobe of the pancreas. In subsequent experiments, the percent of splenic lobe enzyme content that was secreted into the pancreatic duct over $1 \mathrm{~h}$ in response to caerulein $(0.5 \mu \mathrm{g} / \mathrm{kg} / \mathrm{h})$ was determined by direct measurement of enzyme output and splenic lobe content. This allowed calculation of the percent of total pancreatic enzyme content that was secreted while still permitting conservation of some of the pancreas for evaluation of edema and subcellular enzyme redistribution. As shown in Table II, caerulein $(0.5 \mu \mathrm{g} / \mathrm{kg} / \mathrm{h})$ stimulated secretion of $28.0 \%$ of total pancreatic amylase and $0.5 \%$ of total pancreatic cathepsin $B$ into the pancreatic duct over the 1-h period of observation.

Effect of pancreatic duct obstruction on caerulein-stimulated secretion of amylase, cathepsin B, and other lysosomal enzymes. After a 30-min period for stabilization after duct cannulation and the onset of secretin stimulation, the ductal cannula was raised to a vertical position in the "obstructed" group and left in the horizontal position in the "free-flowing" group. Secretin $(2.0 \mathrm{U} / \mathrm{kg} / \mathrm{h})$ was infused for an additional $7 \mathrm{~h}$ in all animals. Thereafter, the vertically placed cannulas of the "obstructed" group were returned to the horizontal position and juice was collected over each of the next $2 \mathrm{~h}$ while the animals received either secretin or secretin plus caerulein $(0.5 \mu \mathrm{g} / \mathrm{kg} / \mathrm{h})$. As shown in Fig. 3, little or no amylase and cathepsin B output from the duct occurred during the first $7 \mathrm{~h}$ in the free-flowing group. Infusion of caerulein during hours 8 and 9 resulted in a substantial increase in the output of both enzymes. Measurement of amylase and cathepsin output during the first $7 \mathrm{~h}$ in the obstructed group was, obviously, not possible. However, after free-flow was restored during hours 8 and 9 , continued infusion of secretin alone resulted in near negligible rates of amylase and cathepsin B output in those animals, while caerulein infusion $(0.5 \mu \mathrm{g} / \mathrm{kg} / \mathrm{h})$ was found to stimulate both amylase and cathepsin output into the pancreatic duct during hours 8 and 9 . The magnitude of cathepsin B as well as amylase secretion stimulated by caerulein in the obstructed group was significantly greater than in the previously free-flowing group $(P<0.01)$. Since caerulein stimulated both amylase and cathepsin B secretion into the duct and the output of each enzyme was greater after the previous period of ductal obstruction than after the prior period of free-flowing secretions, we evaluated the ratio between cathepsin $B$ and amylase secretion after caerulein stimulation in both groups of animals. That ratio (i.e., the ratio of cathepsin B output to amylase output) secreted in response to caerulein stimulation after ductal obstruction $(0.025 \pm 0.004)$ was similar to the ratio of cathepsin B to amylase output in response to caerulein stimulation in animals never subjected to 


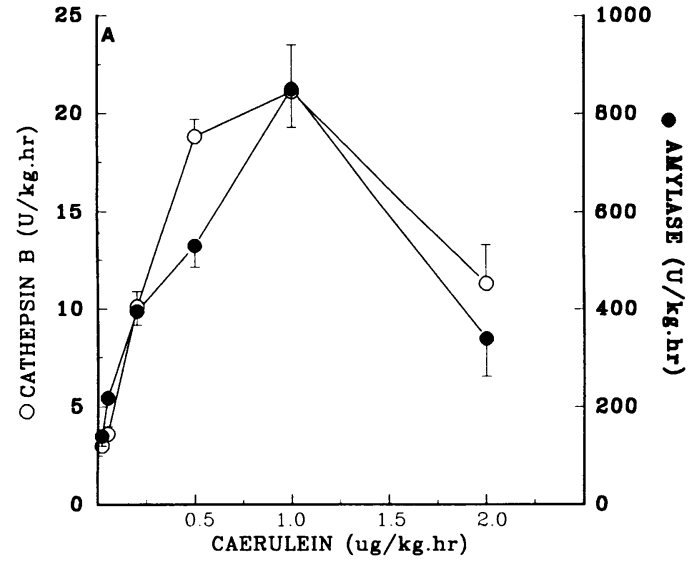

duct obstruction $(0.028 \pm 0.004)(n=9-12$ animals, compare $A$ and $B$ in Fig. 3). Caerulein-stimulated output of the other lysosomal hydrolases measured was also noted to be significantly greater in animals whose pancreatic juice flow had been previously obstructed by a vertically positioned cannula (Table I).

\section{Discussion}

Protein secretion by pancreatic acinar cells is a complex process that, depending on the protein involved, may utilize either regulated or constitutive pathways, and in these structurally polarized cells, be confined to either the apical (i.e., lumenal) or basolateral cell surfaces. The most well characterized of the secretory pathways in pancreatic acinar cells is that used for digestive enzyme secretion. Those proteins appear to be discharged by a highly regulated mechanism that occurs only at the apical surface (11). The pathways involved and the mechanisms responsible for secretion of other proteins by pancreatic acinar cells are less clear. In other types of cells, certain base-

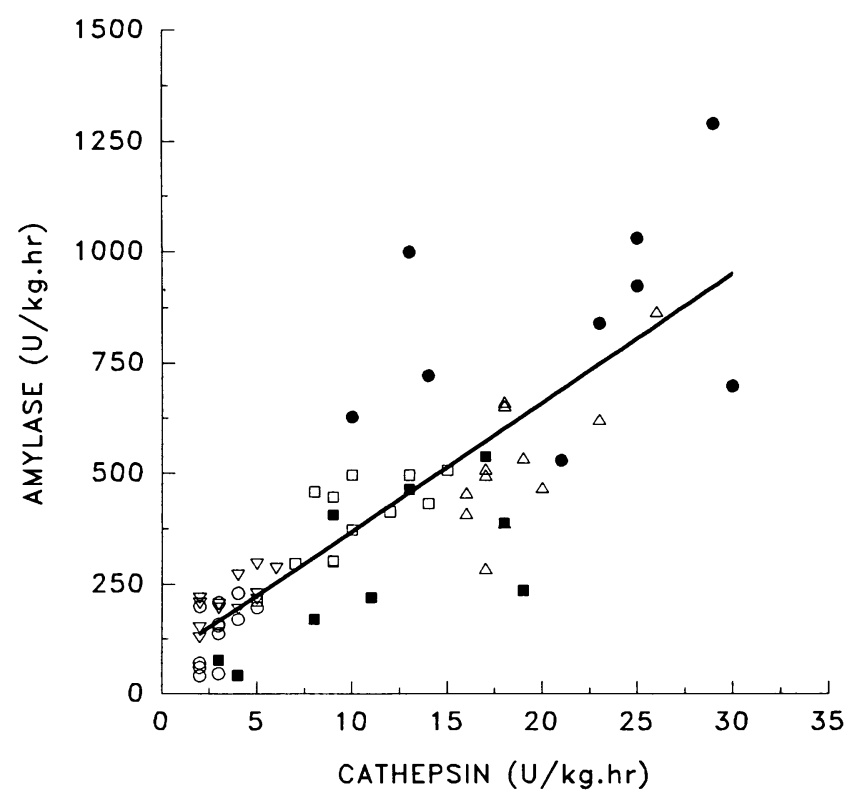

Figure 2. Correlation between cathepsin B and amylase output stimulated by various doses of caerulein. Data are taken from Fig. 1 $A$, while symbols represent different doses of caerulein as follows: (O) $0.02 \mu \mathrm{g} / \mathrm{kg} / \mathrm{h} ;(\nabla) 0.05 \mu \mathrm{g} / \mathrm{kg} / \mathrm{h}$; () $0.20 \mu \mathrm{g} / \mathrm{kg} / \mathrm{h} ;(\Delta) 0.50 \mu \mathrm{g} / \mathrm{kg} / \mathrm{h} ;(\bullet)$ $1.00 \mu \mathrm{g} / \mathrm{kg} / \mathrm{h} ;(\mathbf{(}) 2.00 \mu \mathrm{g} / \mathrm{kg} / \mathrm{h}$. ment membrane proteins such as laminen and heparin sulfate proteoglycan appear to be selectively and constitutively discharged at the basolateral cell surface (12), and it is likely that a similar route for secretion of those proteins is used by pancreatic acinar cells.

Lysosomal hydrolases comprise only a small fraction of acinar cell proteins and only a small portion of the lysosomal enzyme mass is secreted. Those lysosomal enzymes that are not secreted are diverted from the secretory pathway and transported to the acidic prelysosomal (endosomal) compartment. Sorting of lysosomal hydrolases from secretory enzymes is believed to occur in the trans-Golgi network where the mannose6-phosphorylated lysosomal hydrolases are captured by mannose-6-phosphate receptors and packaged in transport vesicles (1). Secretion of lysosomal hydrolases has been observed to occur in many types of cells and it is generally believed that lysosomal enzyme secretion is a constitutive process $(4,5)$. The observation, reported by Rinderknecht and colleagues (2), that the lysosomal enzyme content of human pancreatic juice could be increased by administration of CCK, suggested to us that, at least in the pancreas, lysosomal enzyme secretion might not be constitutive but rather, that it might be a regulated process.

Studies using human subjects and endoscopically collected samples, however, present certain limitations. For example, the fraction of lysosomal enzyme content that is discharged into the ductal space cannot be calculated if human subjects are used because the total pancreatic content of a particular lysosomal enzyme cannot be measured. While the concentration of the lysosomal enzyme in pancreatic juice can be calculated, the output of that enzyme may be underestimated if some portion of that secreted juice passes around the endoscopically placed cannula and escapes collection. Finally, the number of observations that can be made, the ability to do dose-response studies, and the capability of testing the effects of duct obstruction are limited if human volunteers are used as the experimental subjects.

In this paper we report the results of studies that have characterized lysosomal hydrolase secretion by the rabbit pancreas. We have studied secretion of lysosomal hydrolases into the pancreatic juice, and in this way, confined our observations to changes reflecting discharge across the apical surface of exocrine pancreatic cells. We have found that near negligible amounts of cathepsin B and relatively small amounts of other lysosomal enzymes are present in the juice collected from animals infused with the secretagogue secretin, a hormone that primarily stimulates water and bicarbonate secretion from duct cells. Addition of the CCK analogue caerulein results in a 


\begin{tabular}{|c|c|c|c|c|}
\hline \multirow[b]{2}{*}{ Enzyme } & \multicolumn{2}{|c|}{ Free-flowing } & \multirow{2}{*}{$\begin{array}{c}\text { Fold } \\
\text { stimulation }\end{array}$} & \multirow{2}{*}{$\begin{array}{l}\text { Obstructed } \\
\text { Caerulein }\end{array}$} \\
\hline & Secretin & Caerulein & & \\
\hline & \multicolumn{2}{|c|}{$U / k g / h$} & & $U / \mathrm{kg} / \mathrm{h}$ \\
\hline Leucine naphthylamidase & $0.92 \pm 0.08$ & $2.10 \pm 0.18$ & 2.3 & $4.10 \pm 0.53^{*}$ \\
\hline$N$-Acetyl $\beta$-D-galactosaminidase & $2.29 \pm 0.21$ & $6.71 \pm 0.74$ & 2.9 & $11.00 \pm 1.91^{*}$ \\
\hline$N$-Acetyl $\beta$-D-glucosaminidase & $2.40 \pm 0.17$ & $6.46 \pm 0.39$ & 2.7 & $10.96 \pm 1.91^{*}$ \\
\hline Aryl sulfatase & $0.91 \pm 0.14$ & $2.43 \pm 0.37$ & 2.7 & $3.60 \pm 0.54^{*}$ \\
\hline
\end{tabular}

In free-flowing animals, the $1-\mathrm{h}$ output of lysosomal enzymes was measured during infusion of secretin $(2 \mathrm{U} / \mathrm{kg} / \mathrm{h})$ with or without caerulein $(0.5$ $\mu \mathrm{g} / \mathrm{kg} / \mathrm{h})$. In obstructed animals, secretin $(2 \mathrm{U} / \mathrm{kg} / \mathrm{h})$ was infused and the duct obstructed for $7 \mathrm{~h}$ after which the obstruction was released, secretin $(2 \mathrm{U} / \mathrm{kg} / \mathrm{h})$ plus caerulein $(0.5 \mu \mathrm{g} / \mathrm{kg} / \mathrm{h})$ were infused, and lysosomal enzyme output was measured over the next hour. Results represent mean \pm SEM values for four to five animals in each group. Asterisk denotes $P<0.05$ when caerulein-stimulated secretion in obstructed animals was compared with caerulein-stimulated secretion in free-flowing animals.

significant stimulation of the secretion of each of the lysosomal enzymes measured and the dose-response relationship for caerulein-stimulated lysosomal enzyme secretion is closely correlated with that for caerulein-stimulated digestive enzyme (amylase) secretion. These observations strongly suggest that the stimulated secretion of lysosomal enzymes into pancreatic juice reflects an acinar cell response and that the secreted digestive enzymes and lysosomal hydrolases are discharged from the same presecretory compartment, i.e., zymogen granules. An alternative interpretation that cannot be excluded but which, because of its complexity, seems less attractive would be that lysosomal and digestive enzymes are discharged at the apical cell surface from separate compartments, each of which is regulated by secretagogues such as caerulein. Although we have found no evidence to support this latter mechanism, immunolocalization studies at the electron microscopic level would be required to completely resolve this issue. In either case, however, it is clear that apical discharge of lysosomal hydrolases from rabbit acinar cells is, primarily, a regulated process that is closely correlated with the regulated secretion of digestive zymogens.

Rinderknecht et al. (2) reported that some but not all of the lysosomal enzymes that they evaluated were secreted into human pancreatic juice in response to secretagogue stimulation. In contrast, we have evaluated the same lysosomal hydrolases and found that the output of each, in rabbit pancreatic juice, is increased in response to caerulein stimulation. While these discordant observations might reflect species differences, it would seem more likely that they result from the fact that enzyme

Table II. Secretion of Amylase and Cathepsin B

\begin{tabular}{lrr}
\hline \multicolumn{1}{c}{ Value } & Amylase & Cathepsin B \\
\hline $\begin{array}{l}\text { Splenic lobe (percent of total pancreatic } \\
\text { content) }\end{array}$ & $40.0 \pm 1.4$ & $37.9 \pm 0.9$ \\
$\begin{array}{l}\text { Amount secreted (percent of splenic lobe) } \\
\begin{array}{l}\text { Amount secreted (percent of total } \\
\text { pancreatic content) }\end{array}\end{array}$ & $70 \pm 14$ & $1.4 \pm 0.2$ \\
& 28 & 0.5 \\
\hline
\end{tabular}

The content of amylase and cathepsin B within the splenic lobe of the pancreas and within the entire pancreas was measured as described in the text. The percent of total pancreatic amylase and cathepsin B secreted over $1 \mathrm{~h}$ in response to caerulein $(0.5 \mu \mathrm{g} / \mathrm{kg} / \mathrm{h})$ was measured. Results represent mean \pm SEM values from 10 different animals. activity was not immediately measured by Rindernecht et al. after they collected their samples and that, with storage, some but not all of the lysosomal enzymes may have become inactivated.

During a 1 -h period of secretagogue stimulation, $0.5 \%$ of total cathepsin B content and $28 \%$ of total amylase content are discharged from the apical cell surface into the ductal space. Since amylase secretion is believed to occur only via that route and from zymogen granules, these observations suggest that $\sim 1.8 \%$ of total cathepsin B content could potentially be released at the apical cell surface, i.e., that $1.8 \%$ of total cathepsin B is carried out of the cell via the digestive enzyme secretory pathway. This value provides an estimate, therefore, of the degree of lysosomal enzyme missorting that occurs into the regulated pathway for protein secretion. That missorting could result from several potential mechanisms. For example, lysosomal enzymes might be trapped in the bulk flow of digestive zymogens, and thus, inadvertently packaged in condensing vacuoles. Failure of mannose-6-phosphate receptors to capture all of the lysosomal hydrolases could indicate that there are inadequate numbers of receptors or that, for steric or other reasons, binding of enzymes to receptors is constrained. Either of these two possibilities would be compatible with our recent observations that caerulein-stimulated but not basal secretion of cathepsin B at the apical surface of acinar cells in the unobstructed rat pancreas is increased after administration of the lysosomatropic agents chloroquine and methylamine (Hirano, T., A. Saluja, and M. Steer, submitted for publication). Those observations would indicate that regulated apical secretion is at least one of the default pathways for lysosomal enzyme secretion. Another possible explanation for the findings in this paper is that sorting of lysosomal from digestive enzymes during transit through the trans-Golgi network is complete but that, subsequent to sorting, lysosomal enzyme-containing organelles fuse with zymogen-containing structures and lysosomal hydrolases are reinserted into the digestive enzyme secretory pathway. Studies using techniques of immunolocalization will be needed to evaluate these various possibilities. Future studies should also address the possibility that lysosomal hydrolases are also discharged from the basolateral surface of acinar cells via either constitutive or regulated mechanisms since such discharge would have gone undetected during the currently reported studies.

After relief of pancreatic duct obstruction, the magnitude of caerulein-stimulated cathepsin B and amylase secretion is in- 

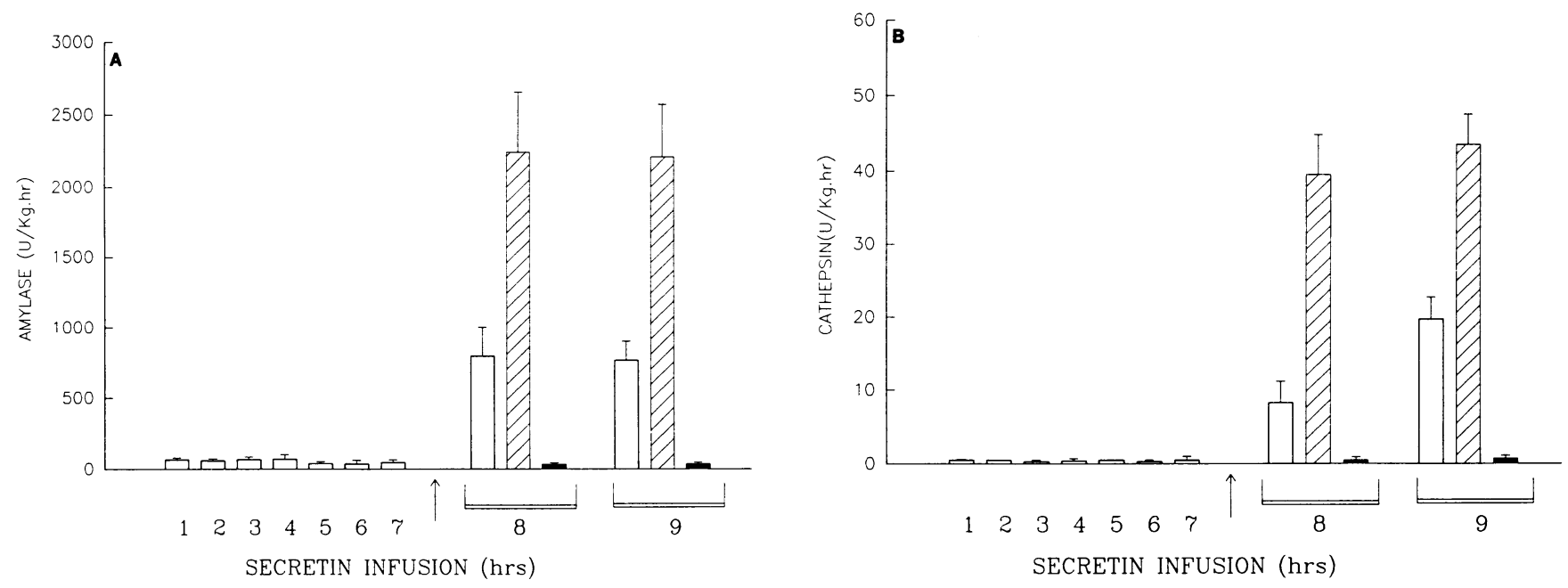

Figure 3. Effect of pancreatic duct obstruction on caerulein-stimulated cathepsin B and amylase secretion. Free-flowing and obstructed animals were stimulated with secretin $(2.0 \mathrm{U} / \mathrm{kg} / \mathrm{h})$ for $9 \mathrm{~h}$ as described in the text. During hours 8 and 9 , obstruction was relieved in the previously obstructed group and secretion was stimulated in both the previously free-flowing (open bars, $n=7$ ) and previously obstructed (hatched bars, $n$ $=12)$ animals by infusion of caerulein $(0.5 \mu \mathrm{g} / \mathrm{kg} / \mathrm{h})$. For comparison, a separate group of previously obstructed animals $($ solid bars, $n=6)$ were stimulated with only secretin $(2.0 \mathrm{U} / \mathrm{kg} / \mathrm{h})$ during hours 8 and 9 . Arrow indicates time at which obstruction was relieved. Data represent mean and vertical bars the SEM values. Caerulein stimulation resulted in significantly greater cathepsin B $(A)$ and amylase $(B)$ output after relief of obstruction $(P<0.01)$.

creased but the ratio of cathepsin B to amylase secretion is not different from that noted after caerulein stimulation of animals never subjected to duct obstruction. This finding indicates that duct obstruction does not increase the relative degree of lysosomal enzyme missorting into the secretagogue releasable compartment but that duct obstruction does expand the enzyme content of that compartment. Presumably, this reflects the accumulation of mature but undischarged zymogen granules. The observation that the unstimulated output (i.e., output during secretin but not caerulein stimulation) of lysosomal enzymes does not increase after relief of duct obstruction indicates that duct obstruction does not increase the apical constitutive release of lysosomal enzymes.

In a recent report, we described the effects of duct obstruction on the subcellular localization of digestive and lysosomal enzymes (3). The amylase content of the rabbit pancreas was found to be increased after $7 \mathrm{~h}$ of duct obstruction but cathepsin B content remained unchanged. On the other hand, the percent of total cathepsin B but not that of amylase contained within the zymogen granule-enriched subcellular fraction was increased after duct obstruction. Finally, organelles resembling zymogen granules were noted to have an increased content of lysosomal hydrolases but not digestive enzymes after duct obstruction. We concluded that duct obstruction led to lysosomal and digestive enzyme colocalization within those granule-like organelles and that, since the lysosomal enzyme cathepsin B can activate trypsinogen $(6,7)$ and trypsin can activate the remaining digestive zymogens, the colocalization of lysosomal and digestive enzymes could result in activation of digestive enzymes within those organelles (13). Based on the observations reported in this paper we are led to conclude that the contents of the granule-like organelles that appear after duct obstruction and that contain colocalized lysosomal and digestive enzymes are not subject to caerulein-stimulated secretion after duct obstruction has been relieved, because if they were secreted, a rise in the cathepsin B to amylase ratio in the secreted juice would have been anticipated. The ultimate fate of these organelles may be of considerable importance to the pathogenesis of acute pancreatitis since it is within these structures that digestive enzyme activation could occur.

\section{Acknowledgments}

We thank Dr. J. Meldolesi, University of Milan, for his helpful suggestions and critical review of the manuscript.

This work was supported by National Institutes of Health grants DK-31396 and DK-31394. T. Hirano was supported by grant B-62480282 from the Ministry of Education, Science and Culture and the Ministry of Health and Welfare of Japan. M. M. Lerch was supported by grant Le 625/1-1 from the Deutsche Forschungsgemeinschaft.

\section{References}

1. Kornfeld, S. 1986. Trafficking of lysosomal enzymes in normal and disease states. J. Clin. Invest. 77:1-6.

2. Rinderknecht, H., I. G. Renner, and H. H. Koyama. 1979. Lysosomal enzymes in pure pancreatic juice from normal healthy volunteers and chronic alcoholics. Dig. Dis. Sci. 24:180-186.

3. Saluja, A., M. Saluja, A. Villa, U. Leli, P. Rutledge, J. Meldolesi, and M. Steer. 1989. Pancreatic duct obstruction in rabbits causes digestive zymogen and lysosomal enzyme colocalization. J. Clin. Invest. 84:1260-1266.

4. Kelly, R. B. 1985. Pathways of protein secretion in eukaryotes. Science (Wash. DC). 230:25-32.

5. Burgess, T. L., and R. B. Kelly. 1987. Constitutive and regulated secretion of proteins. Annu. Rev. Cell Biol. 3:283-93.

6. Greenbaum, L. A., and A. Hirshkowitz. 1961. Endogenous cathepsin activates trypsinogen in extracts of dog pancreas. Proc. Soc. Exp. Biol. Med. 107:7476.

7. Figarella, C., B. Miszczuk-Jamska, and A. J. Barrett. 1988. Possible lysosomal activation of pancreatic zymogens. Activation of both human trypsinogens by cathepsin B and spontaneous acid activation of human trypsinogen 1. Biol. Chem. Hoppe-Seyler. 369(Suppl.):293-298.

8. Bernfield, P. 1955. $\alpha$-Amylase. Methods Enzymol. 1:149-151.

9. McDonald, J. K., and S. Ellis. 1975. On the substrate specificity of cathep$\sin B_{1}$ and $B_{2}$ including a new fluorogenic substrate for cathepsin $B_{1}$. Life Sci. 17:1269-1276.

10. Lowry, O. H., N. J. Rosebrough, A. L. Farr, and R. J. Randall. 1951. Protein measurement with the folin phenal reagent J. Biol. Chem. 193:265-275.

11. Palade, G. 1975. Intracellular aspects of the process of protein secretion. Science (Wash. DC). 189:347-358.

12. Caplan, M. J., J. L. Stow, A. P. Newman, J. Madri, H. C. Anderson, M. G. Farquhar, G. E. Palade, and J. D. Jamieson. 1987. Dependence on $\mathrm{pH}$ of polarized sorting of secreted proteins. Nature (Lond.). 329:632-635.

13. Steer, M. L., J. Meldolesi, and C. Figarella. 1984. Pancreatitis: The role of lysosomes. Dig. Dis. Sci. 29:934-938. 